\title{
An explanation for mudflows
}

\author{
L. E. VALLEJO (1979). Géotechnique 29, No. 3, 351-354
}

\section{Mr R. N. Morris, Colorado State University}

The Author seeks to explain observed low mobilization slope angles for the slope movements described by Hutchinson (1970), using Bagnold's $(1954,1956)$ grain flow theory. Grain flow is the motion produced by intergranular dispersive stresses acting on cohesionless grains within a Newtonian fluid. Originally developed for sediment transport problems, Bagnold's theory has also been applied to rapid mass movements such as catastrophic rockfalls and debris flows. Extension of the theory to slower mass flows might be a promising approach to a class of slope movements that has long defied conventional soil mechanics treatment. Unfortunately, the grain flow theory requires the intergranular mud described by the Author to behave like a Newtonian fluid. Furthermore, Bagnold's theory applies only to spherical grains of uniform size; this places severe restraints on application of the theory which the Author does not treat.

Hutchinson (1970) uses the term 'mudflow' to describe a slow, half-sliding, half-flowing movement. Although this usage seems common in British literature, most North American workers would call this type of phenomenon 'earthflow', reserving 'mudflow' for rapid, very fluid, channelized movements such as those which occur at Wrightwood, California (Morton \& Campbell, 1974). There is some evidence that these rapid movements may display grain flow behaviour. The question here is whether or not it is realistic to treat the slower flows at Beltinge as grain flow phenomena.

Although they play a role in Bagnold's theory, the shear and slope angle equations used by the Author do not in themselves define grain flow behaviour. Examination of the differential equations for grain flow motion proposed by Bagnold (1954) shows that the intergranular mud at Beltinge must possess an amazingly high viscosity to account for the very slow movement rates reported by Hutchinson (1970). Furthermore, the moisture contents of the Beltinge mud are well below the liquid limit, suggesting that a valid rheological model for the mud must contain components other than simple Newtonian viscosity. The rheological model of Komamura \& Huang (1974), for example, includes both viscous and plastic components for soils with the moisture contents observed at Beltinge. These considerations suggest that the intergranular mud is not the Newtonian fluid required by grain flow theory.

The Author's argument hinges on his claim that his equation (5) (Bagnold's equation for the minimum slope angle for flowage) is superior to his equation (6) (the Skempton \& DeLory (1957) equation for the minimum sliding angle) for the purpose of predicting mudflow mobility. In fact, equation (5) simply restates the effective stress principle for the general case of neutral stress produced by an intergranular fluid of unspecified nature. If the fluid is water, equations (5) and (6) both yield the same result. Furthermore, it can easily be shown that the two equations are equivalent. Examination of the term $\left(\gamma_{\mathrm{s}}-\gamma_{\mathrm{f}}\right) C$ shows that this term is equivalent to the buoyant unit weight. This is because, in a saturated twophase system, the volumetric grain concentration $C$ is equal to unity minus the porosity. Substitution of $(1-n)$ for $C$ yields the term $\left(\gamma_{\mathrm{s}}-\gamma_{\mathrm{f}}\right)$ $\times(1-n)$, which is the equation that Terzaghi (1943) used to define buoyant unit weight. Consequently, substituting the buoyant unit weight into equation (5) yields equation (6), provided the solid and fluid phases are consistently defined. It is not surprising that these two equations are equivalent as they both serve only to resolve the weight of the moving mass into normal and shear components and to relate those components to the shear resistance. The form of the equations depends only on the nature of a two-phase solid/liquid systcm and docs not imply anything about the mechanism of motion.

Neither conventional slope stability analyses nor grain flow theory appears adequate to model earthflows such as that at Beltinge. The conventional methods apply to soil behaviour in a viscoplasto-elastic state and underestimate mobility; grain flow theory applies to viscous flow and overestimates mobility. As earthflows apparently exhibit both viscous and plastic behaviour, a truly valid theory for earthflow movement must account for both the viscous and the plastic components of deformation. Viewed in this context, the Author's primary contribution is that the mobility of slow flows can be better predicted by defining the pore fluid as being the intergranular mud rather than the pore water. 


\section{REFERENCES}

Bagnold, R. A. (1954). Experiments on a gravity-free dispersion of large solid spheres in a Newtonian fluid under shear. Proc. R. Soc., Series A 225, 49-63.

Bagnold, R. A. (1956). The flow of cohesionless grains in fluids. Phil. Trans. R. Soc., Series A 249, 235-297.

Hutchinson, J. N. (1970). A coastal mudflow on the London Clay cliffs at Beltinge, North Kent. Géotechnique 20, No. 4, 412-438.

Komamura, F. \& Huang, R. J. (1974). New rheological model for soil behavior. J. Geotech. Engng Div. Am. Soc. Civ. Engrs 100, GT 7, 807-824.

Morton, D. M. and Campbell, R. H. (1974). Spring mudflows at Wrightwood, Southern California. Q. J. Engng Geol. 7, 377-384.

Skempton, A. W. \& DeLory, F. A. (1957). Stability of natural slopes in London Clay. Proc. 4th Int. Conf. Soil Mech., London 2, 378-381.

Terzaghi, K. (1943). Theoretical soil mechanics. New York: Wiley.

\title{
Bedding error in triaxial tests on granular media
}

\author{
R. W. SARSBY, N. KALTEZIOTIS and E. H. HADDAD (1980). Géotechnique 30, No. 3, \\ 302-309
}

Mr R. J. W. McDermott, Gwynedd County

Council, North Wales

The Authors have shown that lubricated ends can be calibrated for a range of particle sizes and this therefore further substantiates their benefit to triaxial testing.

As indicated in the Authors' Fig. 6, a number of repeat calibrations should be made to take account of the effects of any random variations. I have found that a useful expedient in standardizing the preparation of lubricated ends is to preload them overnight by placing a $20 \mathrm{kgf}$ weight (giving $25 \mathrm{kN} / \mathrm{m}^{2}$ for a $100 \mathrm{~mm}$ dia. platen) on top of the lubricated ends interspersed with a flat $100 \mathrm{~mm}$ dia. Perspex or metal block with tissue paper at either end to prevent sticking. The result the next morning is a uniform flat rubber disc with a uniform layer of grease beneath the rubber disc perceptibly free of air bubbles (McDermott, 1972).

I have studied the effects of axial bedding error and boundary membrane penetration for fine sand in both isotropic $(C R=1)$ and anisotropic $(1<\mathrm{CR}=4)$ consolidation tests, as part of a study to formulate a self-consistent model for the recoverable component of deformation for granular material. I was concerned with the recurrent bedding error due to particle embedment both at the lubricated ends (axial) and at the membrane boundary (radial) which affects first load and in particular cyclic strain data.

Consider a sand sample undergoing small strains in an axisymmetric (triaxial) stress system $\left(\sigma_{2}^{\prime}=\sigma_{3}^{\prime}\right)$. Then

$$
\begin{aligned}
v & =\varepsilon_{1}+\varepsilon_{2}+\varepsilon_{3} \\
& =\varepsilon_{1}+2 \varepsilon_{3}
\end{aligned}
$$

where $v$ is measured natural volumetric strain, $\varepsilon_{1}$ is measured natural axial strain and $\varepsilon_{2,3}$ are deduced natural radial strains. For an isotropic material in a $\mathrm{CR}=1$ test

$$
\varepsilon_{1}=\varepsilon_{2}=\varepsilon_{3}
$$

and from equation (1)

$$
\varepsilon_{1}=\varepsilon_{3}=v / 3
$$

Figure 1 shows that the as measured strains for dense fine sand after a few cycles in a $C R=1$ test follow equation (2) closely and this implies that the bedding errors in the axial and radial directions are either insignificant or equal in magnitude. Similar results indicating the isotropic nature of a range of sands in $\mathrm{CR}=1$ tests after cyclic loading are given by El-Sohby (1964) and Andrawes (1964) (reported in El-Sohby \& Andrawes, 1973).

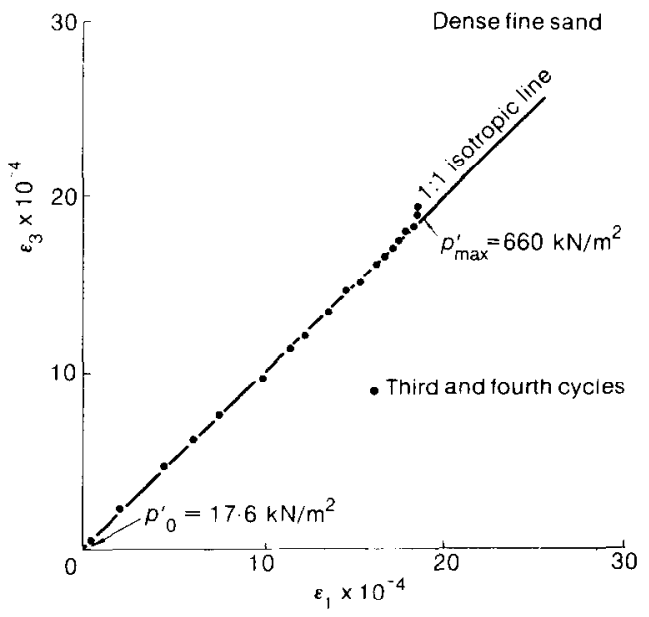

Fig. 1. Relationship between reload and unload for CR $=1$ test 